International Journal of Heritage, Tourism and Hospitality Vol. (13), No. (1), March, 2019

By: Faculty of Tourism and Hotels, Fayoum University

\title{
Goddess Nekhbet Scenes on Royal Monuments during the Fifth and Sixth Dynasties \\ Saraa El-Shamy* ${ }^{*}$ Osama Ibrahim Taher Hassan Walid Shaikh Al Arab \\ Faculty of Tourism and Hotels, Fayoum University
}

\begin{abstract}
Nekhbet was an early Predynastic local divinity in the Egyptian mythology. Her ancient Egyptian name meant She of Nekheb, she was the patron deity of the city of Nekheb. Ultimately, she became the tutelary deity of Upper Egypt and one of the two patron deities for all of Ancient Egypt when it was unified. Nekhbet and her Lower Egyptian counterpart Wadjet often appeared together as the Nebty name which meant [he/she] of the Two Ladies. It is one of the five titles of each ruler. This study aims to shed more light on the cult of goddess Nekhbet throughout her names, titles and iconographies appeared on royal monuments during the fifth and sixth dynasties. Geographical epithets of Nekhebet were the most common and important ones, especially those that connected with the III $^{\text {th }}$ Nome of Upper Egypt and its capital, Nekhen. Nekhbet beard several epithets which show her relationship with Upper Egypt and its principal sanctuary. Nekhbet attained epithets that refered to her mighty character «3wt- ${ }^{-}$:with outstretched wings » and « $8 m 3 t-p \underline{d}(w) t$ : Stretcher of Bows ».
\end{abstract}

Keywords: Nekhbet, Old Kingdom, Vulture, Nekhen, El-Kab.

\section{Introduction}

Nekhbet ${ }^{*}$ was the vulture goddess of Upper Egypt. She was a mythical mother of the king. She wasn't associated in any form of family ties with any deities but she was identified as the mother of Horus in the Pyramid Texts ${ }^{\dagger}$. Nekhbet takes the role of protective nurse to the monarch in birth houses; this led to a later identification with the Greek goddess of childbirth: Eileithyia

Nekhbet was the right eye of the Sun gods Re and Atum; as she guaranteed their powers. She was called «wnmt-n-Re: Right eye of Re» leading to different iconographies of the goddess (vulture, cobra, eye) ${ }^{\S}$. She may have been a primeval goddess of the sky, rival to Horus the falcon god, but in the Pyramid Texts, she was visualized as a great wild cow. "Your mother is the great wild cow who dwells in Nekheb" ${ }^{\text {*** }^{*}}$. Nekhbet took the form of the largest flying bird known to the Egyptians: the white vulture. Alan Gardiner identified the species that was used in the divine iconography as a griffon vulture ${ }^{\dagger \dagger}$ A creature that the Egyptians thought only existed as females (not knowing that, lacking sexual dimorphism, the males were identical) ${ }^{\sharp}$. The vulture's

\footnotetext{
* I would like to express my sincere gratitude to Dr. Walid Shaikh Al Arab for his valuable comments, corrections and suggestions on a draft version of this paper, which have led to significant improvement on the presentation and quality of this paper.

* For more about goddess Nekhbet, see Hart (2005), The Routledge Dictionary of Egyptian Gods and Goddesses, pp. 101-102; Wilkinson (2003), The Complete Gods and Goddesses, pp. 213-215; Leitz ( 2002), LGG IV, OLA 113, pp. 301- 303; Capart (1946), Quelques observations sur la déesse d' El-Kab, pp. 1-15. نور الدين عبد الحليم. 2010. الديانة المصرية القديمة ج. الأول: المعبودات، ط. 2.

$\dagger$ Wahlberg (2002), Goddess Cults in Egypt Between 1070 BC and 332 BC, Ph.D Thesis, School of Historical Studies, University of Birminghan, p. 123.

* Hart (2005), The Routledge Dictionary of Egyptian Gods and Goddesses, p. 102.

$\S$ Preys (2010), "Nekhbet, L'øil droit du dieu solaire", in: Rd'É 61, p. 177.

** Lesko (1999), The Great Goddesses of Egypt, p. 65.

† Bailleul-LeSuer (2012), Between Heaven and Earth: Birds in Ancient Egypt, pp. 61-62.

\$ L.C.F. (2013), A Comprehensive List of Gods and Goddesses of Ancient Egypt, p. 221. Book available on: https://www.scribd.com/doc/154978105/Gods-and-Goddesses-of-Ancient-Egypt
} 
cult dated to the Predynastic periods in the city of Nekhen ${ }^{*}$. Nekhbet could also appear as another dangerous animal: the long-horned wild cow of the marshlands ${ }^{\dagger}$.

Nekhbet was associated with kings in one of their five titularies (Nbti which refered to the two ladies of Upper and Lower Egypt (Nekhbet and Wadjet) ${ }^{\ddagger}$.

In religious scenes especially in the New Kingdom; the king was accompanied by his queen. Queens were clearly outside the protection of Nekhbet and Wadjet. As queens of Egypt were an incarnation of Nekhbet - or of Wadjet - and that; they played the role of the goddesses with the king. That was clearly noted in their hairstyle, dresses and scepters ${ }^{\S}$.

Nekhbet's main cult center was the city of Nhn: El-Kom Al-Ahmar ${ }^{* *}$. It was the capital of the III $^{\text {rd }}$ Nome of Upper Egypt ${ }^{\dagger \dagger}$. The religious and political capital of Upper Egypt at the end of the Predynastic period (c. 3200-3100 BC). The shrine of Nekhbet at Nekheb is one of Egypt's earliest temples. Nekhbet name $\left(N h b t^{\star *}\right)$ means "She of Nekhen"\$§. During the Old Kingdom, it was written with two different determinatives $f_{\text {. }}$ and (II) $* * *$.

Firstly in 1982, Voorschoten Matthieu Heerma Von Voss ${ }^{\dagger \dagger \dagger}$ wrote a short review about the goddess Nekhbet entitled "Nechbet" in $L \ddot{A}$ : IV. In 1997, Hasanen Azza prepared a doctoral dissertation (Ph.D) ${ }^{+*}$ about goddess Nekhbet and Wadjet. In 2002, Leitz Christian ${ }^{\S \S}$ also addressed goddess Nekhbet in his valuable lexikon. Five years later in his illustrated dictionary, L'Egypte ancienne et ses dieux, Corteggiani Jean-Pierre ${ }^{* * * *}$ wrote a review on Nekhbet.

The aim of this study was to provide a detailed analysis of the nature of the goddess Nekhbet throughout her names, titles and iconographies appeared on royal monuments during the fifth and sixth dynasties.

\section{Documents}

This study was based on the seven known documentations for the goddess Nekhbet appeared on royal monuments during the fifth and sixth dynasties.

* Budge (1904), The Gods of the Egyptians or Studies in Egyptian Mythology II, p. 372.

† Pinch (2002), Handbook of Egyptian Mythology, p. 212.

Budge (1904), The Gods of the Egyptians or Studies in Egyptian Mythology, vol. I, p. 438.

$\S$ Werbrouck (1952), "La déesse Nekhbet et la reine d'Égypte", in: HroznY், BedŘich (eds.), Archiv Orientální, XX,Czechoslovakia, pp. 197- 198.

${ }^{* *}$ Nxn the name of the city dedicated to goddess Nekhbet. On the Nile's left bank was the ancient city of El-Kom AlAhmar or El-Kab where the ancient capital of the $3^{\text {rd }}$ Nome of Upper Egypt existed, see Gauthier (1926), Dictionnaire des noms géographiques III, p. 99.

†T The name of Nekhen belongs not only to the Nome, but to the city that we consider the primitive capital by virtue to his chief town. The city of Nxn was cited several times in the Pyramids Texts which oppose the Horus of Nekhen, the Souls of Nekhen and Nekhen's Watchers (wrSw). Nekhen was mainly devoted to Horus of Nekhen. It is located at Kom el Ahmar, west of the River, and a little to the south in relation to Kl-Kab. The city encloses a temple enclosure from which was drawn on objects from the archaic period (vase and the club of King Scorpion, the club and the palette of Narmer, alabaster jar and a granite vase of King Khasekhemwy). Montet (1961), Géographie de l'Égypte Ancienne II, p. 42.

$\$$ Wb II, p. 309.

$\$ \S$ Černy (1951), Ancient Egyptian Religion, p. 23

${ }^{* * * *}$ Gardiner (1975), Egyptian Grammer Being an Introduction to the Study of Hieroglyphs, pp. 482- 498.

Tit Voorschoten, Matthieu Heerma Von Voss.'Nechbet' in: Otta Eberhard and HelckWolfgang (1982), LÄ IV, pp. 366-367.

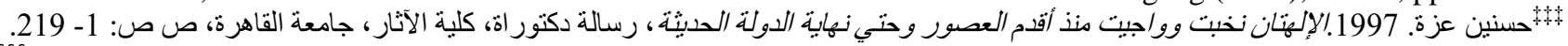

${ }_{\S \S \S}^{\$}$ LGG IV, pp. 301-303.

${ }^{* * * *}$ Corteggiani (2007), L'Égypte ancienne et ses dieux: dictionnaire illustré, pp. 366-368. 
The first document was found in the south wall of the entrance niche, valley temple of Sahure at Abusir*. A block made out of painted limestone, now preserved in the Egyptian Museum of Cairo JE 395322 and JE 395323†. It showed king Sahure (2487-2475 B.C) being suckled by goddess Nekhbet in the presence of god Khnum. Nekhbet was represented in an anthropomorphic form as a woman wearing a tripartite wig topped by a vulture cap. She wore a chocker around her neck and wsh-collar. She was dressed in a tall-tight dress with two wide straps along with bracelets and anklets. Her left hand was embracing Sahure from the back while the right one was bent to hold her breast. Her skin was colored in pale cream. Above the head of Nekhbet, five short columns of inscriptions, traced from left to right $(\downarrow \leftarrow)$

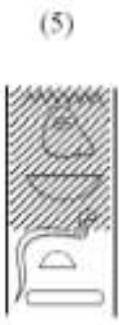

(4)

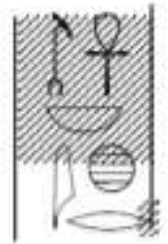

(3)

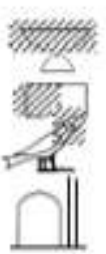

(2)

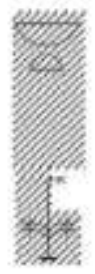

(1)

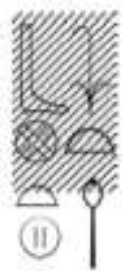
Hdt $N / m$
nbt Pr-wr
2) nbt list-ntr $\tilde{S}_{m}{ }^{2} w$
4) $n h$ w3s $n b$ hry

5) In fnd $n b d t$

(1) Nekhbet The White of Nekhen ${ }^{\ddagger}$, ${ }^{(2)}$ Mistress of the Upper Egyptian Divine Palace ${ }^{\S}$ (3) Mis of the Great-House ${ }^{* *}{ }^{(4)}$ All life and happiness for your part ${ }^{(5)}$ are for your nostrils, forever.

${ }^{*} \mathrm{PM} \mathrm{III}^{1}$, p. 331

${ }^{\dagger}$ Current location in the Museum is EMC- R36-N3- c. Their ID numbers JE 39532/3, SR 2/ 14932.1/2 and GEM 45821 (a) / (b).

\$Dt Nxn 'The White of Nekhen' or 'Nekhen the White' it was a late appellation of the city of el-Kab in the $3{ }^{\text {rd }}$ Nome of Upper Egypt. See Gauthier (1927), Dictionnaire des noms géographiques IV, p. 147.

$\S$ HAt-nTr Smaw is the archaic sanctuary of Upper Egypt. Cf. Gauthier (1927), Dictionnaire des noms géographiques IV, p. 104.

pr-wr is the sanctuary of Upper Egypt related to goddess Nekhbet at El-Kab. It was the opposite of Pr-Nsr of Lower Egypt. See. Gauthier (1925), Dictionnaire des noms géographiques II, p. 67. 
Figure 1: Nekhebet is suckling Sahure in the Presence of Khnum

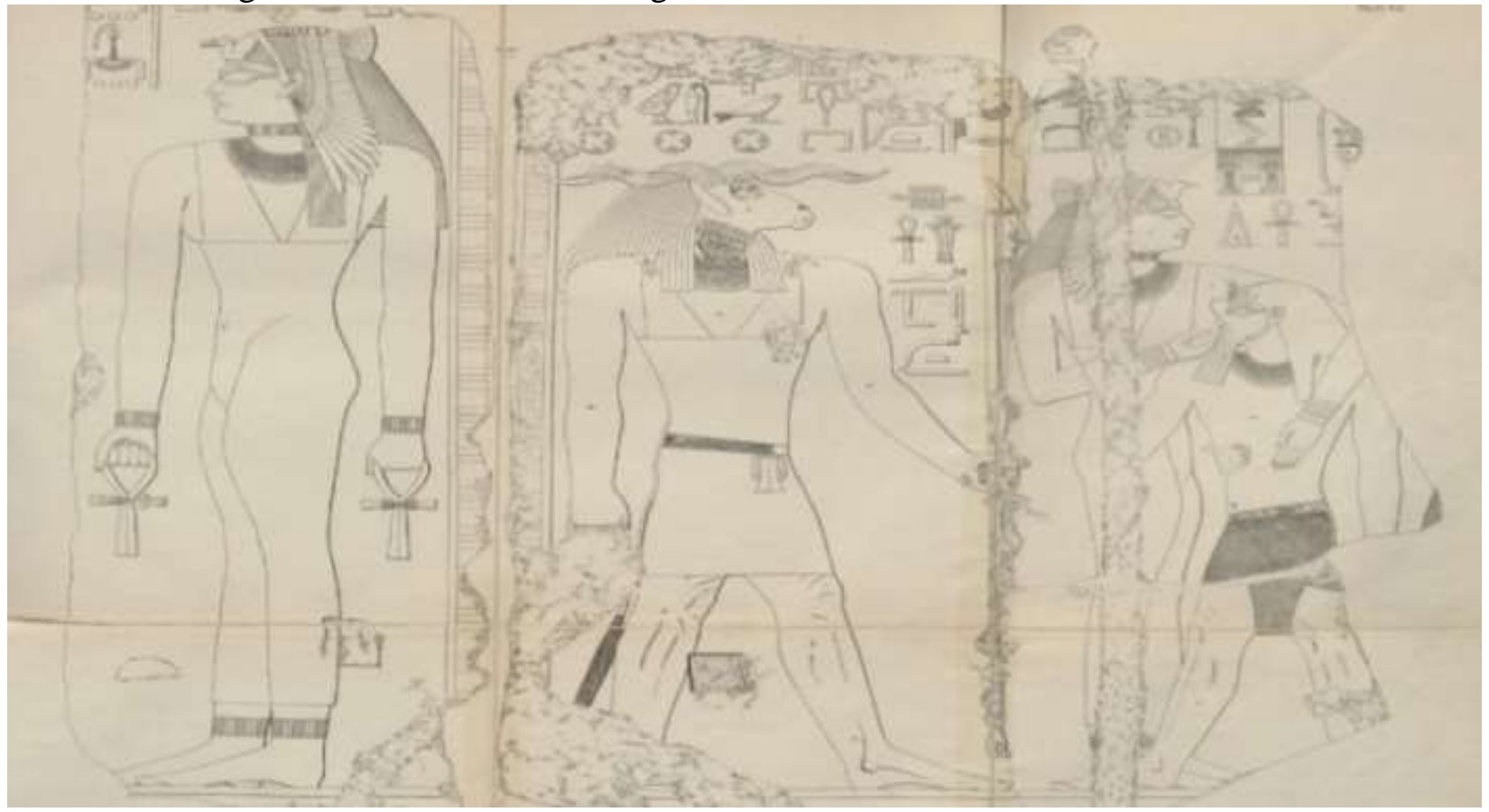

After: Borchadt (1913), Das grabdenkmal des königs Sảhu-Rer II, pl. 18.

On the next block goddess Nekhbet was standing in the anthropomorphic form wearing a vulture cap and a shoulder-length wig. She wore a tall-tight dress with two wide straps leaves only one of her breasts exposed. She also wore a necklace and an wsh-collar as well as bracelets and anklets. She held ' $n$ h-signs of life in her both lowered hands. Her skin was colored pale cream. Above her head two short columns of inscriptions were traced from left to right $(\rightarrow \downarrow)$

(1)

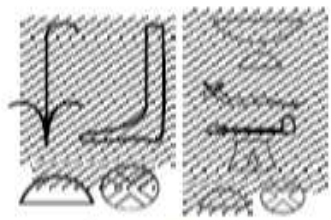

1) $N h b$

${ }^{1)}$ Nekhbet
(2)

2) $\mathrm{nbt} F \mathrm{gt}$
${ }^{2)}$ Mistress of $F\left\ulcorner g t^{T}\right.$
(3)

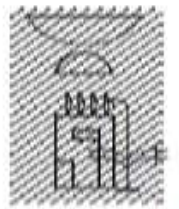

3) nbt hat-nt!. Smew

${ }^{2)}$ Mistress of Upper Egyptian Divine Palace.

*fagt was the name of the Serapeum of the $3^{\text {rd }}$ Nome of Upper Egypt, where the jaws of Osiris were kept; it was dedicated to the goddess Nekhbet taking the form of goddess Hathor called - OH Goddess Nekhbet was called "Mistress of Fagt" on the copy of the decree of Canope from Kom el-Hisn. Brugsch wanted to recognize in this place the rare name FkAt assimilates between Fagt and FkAt is certainly incorrect may be in Kom el-Hisn was another Fagt but it's entirely different from Fagt of Upper Egypt. See Gauthier (1925), Dictionnaire des noms géographiques II, p. 160. 
The second document was a limestone block discovered in Saqqara, in the floor of a court close to the southern church in the Monastery of Apa Jermias in 1951 A.D. It came originally from the funerary temple of Sahure at Abusir ${ }^{*}$. Now preserved in the Egyptian Museum, Cairo ${ }^{\dagger}$ TR 28.2.21.17. It represented goddesses Wadjet and Nekhbet while giving symbols of authorities to king Sahure. On the left side, goddess Nekhbet was standing, wearing the vulture cap on her head. She was holding in her hand the w3s-sceptre with an ' $n h$ - sign attached to its curve and directed in Sahure. Above their heads were the sun disk surrounded by two vultures \{the representation of goddess Nekhbet\} stretching out their wings and grasping in their claws the $5 n$ sign of eternity and the 'nh-sign of life. Above goddess Nekhbet were three rows (1-3) of inscriptions written from right to left $(\downarrow \leftarrow)$

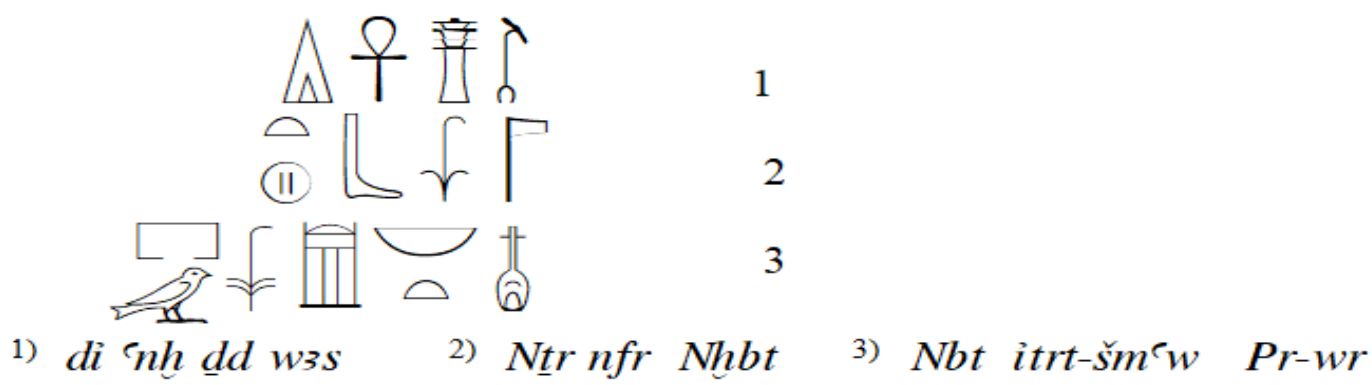

${ }^{(1)}$ She gives life, stability, and domination ${ }^{(2)}$ The perfect goddess; Nekhbet ${ }^{(3)}$ Mistress of itrt$\check{s} m^{\top} w^{\ddagger}$ and the $P r-w r$.

Figure 2: Nekhbet and Wadjet are Giving Symbols of Authorities to Sahure.

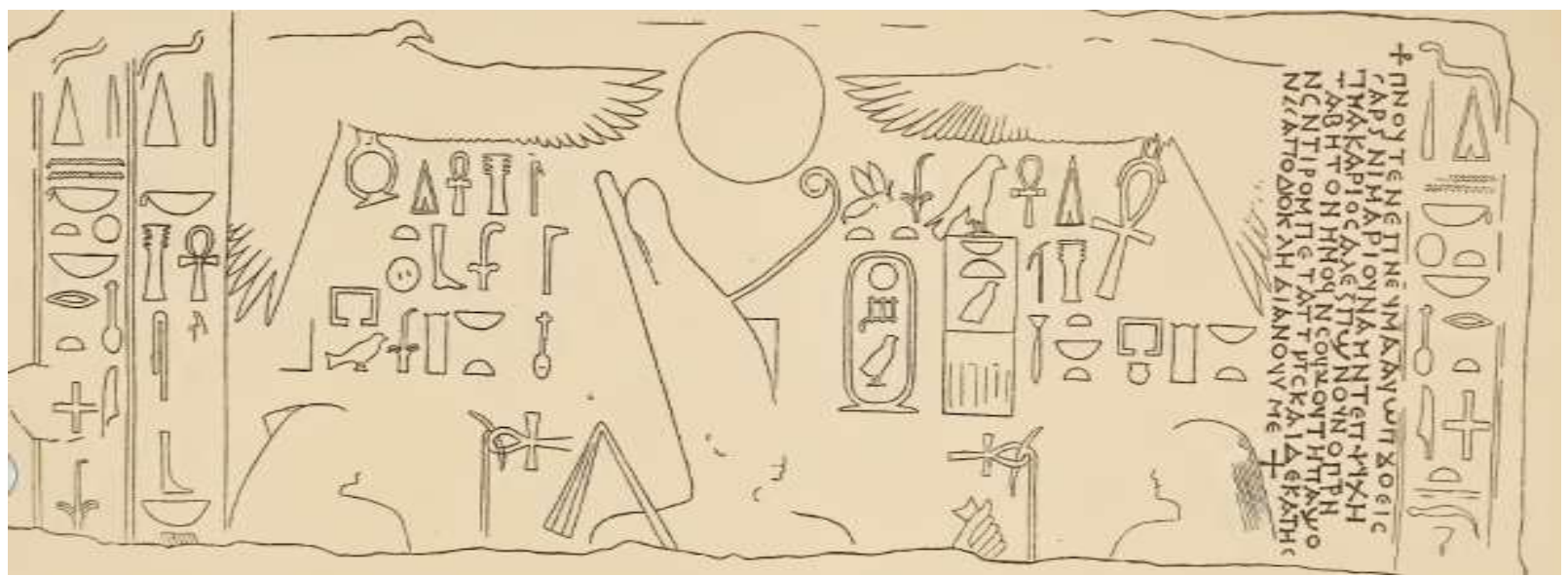

After: Quibell (1912), The Monastery of Apa Jeremias, pl. 89.

${ }^{*}$ PM III ${ }^{1}$, p. 329.

${ }^{\dagger}$ Current location in the museum EMC- R41- W2- f. It's ID numbers TR 28.2.21.17 and SR2/ 14866. This piece was excavated by J. Quibell for the EAS (Egyptian Antiquities Services) from 1908-1910.

" 'Itrt $\breve{S} m^{\top} w^{\prime \prime}$ The Chapel of Upper Egypt" it was pointing to Upper Egypt, not the city of Coptos as Brugsch believed. Originally, the chapel of Upper Egypt was at Hieraconpolis, while that of Lower Egypt amounted to Buto. See Gauthier (1925), Dictionnaire des noms géographiques I, p. 122. 
The third document came from the western wall of the entrance room south of the funerary temple of Sahure at Abusir ${ }^{*}$. Now preserved in the Egyptian Museum, Cairo TR 6.12.24.9 ${ }^{\dagger}$. The scene represented six gods and goddesses standing with their upper bodies bending a little forward and carrying a tray loaded with offerings and three ${ }^{\top} n h$-signs hanging from them along

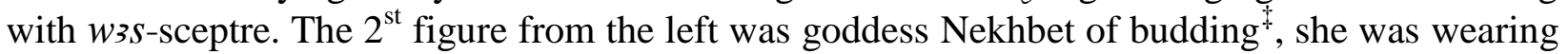
a tripartite straight wig and around her neck the wsh-collar and above it a chocker. She was dressed in a tall-transparent tight dress with two wide straps tied on her shoulder and leaves one of her breasts expose.

Figure 3: Nile Fecundity Figures.

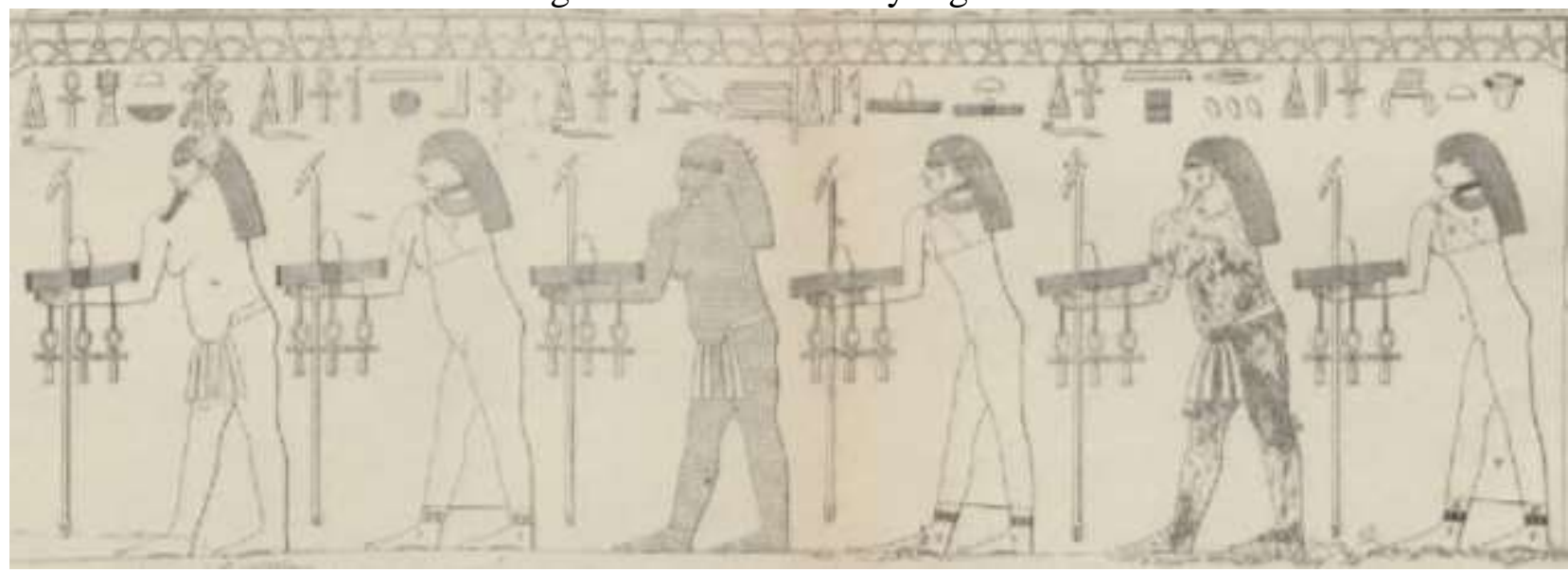

After: Borchadt (1913), Das grabdenkmal des königs Sa $a^{3} h u-R e^{\Upsilon}$ II, pl. 30.

Before and above Nekhbet's head a row of inscription read $(\rightarrow)$

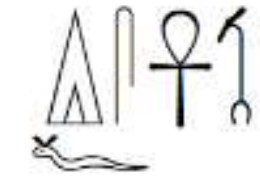

di.f 'nh snb wzs

(She) gives life, health, and domination

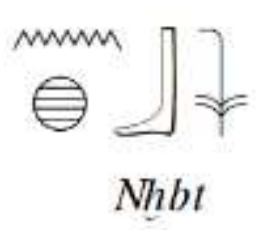

Goddess Nekhbet

The forth document was a limestone block was found in the north of the hall inside the valley temple of Sahure ${ }^{\S}$. The scene showed the illustration of the vulture-goddess Nekhbet hovering over the king with outstretched wings while grasping the $\breve{S} n$-sign in her claws. Above and after the Vulture were her titles traced from right to left $(\downarrow \leftarrow)$

* PM IIII ${ }^{1}$, p. 330.

'Current location in the Museum EMC- R36- S1- a.ID number TR 6.12.24.9 and SR 2/ 14956.

$\ddagger$ For more information, see Sethe, "Die Inschriften" in: Borchadt (1913), Das grabdenkmal des königs SaAHuRealI, p.109.

${ }^{\S} \mathrm{PM} \mathrm{IIII}^{1}$, p. 326. 


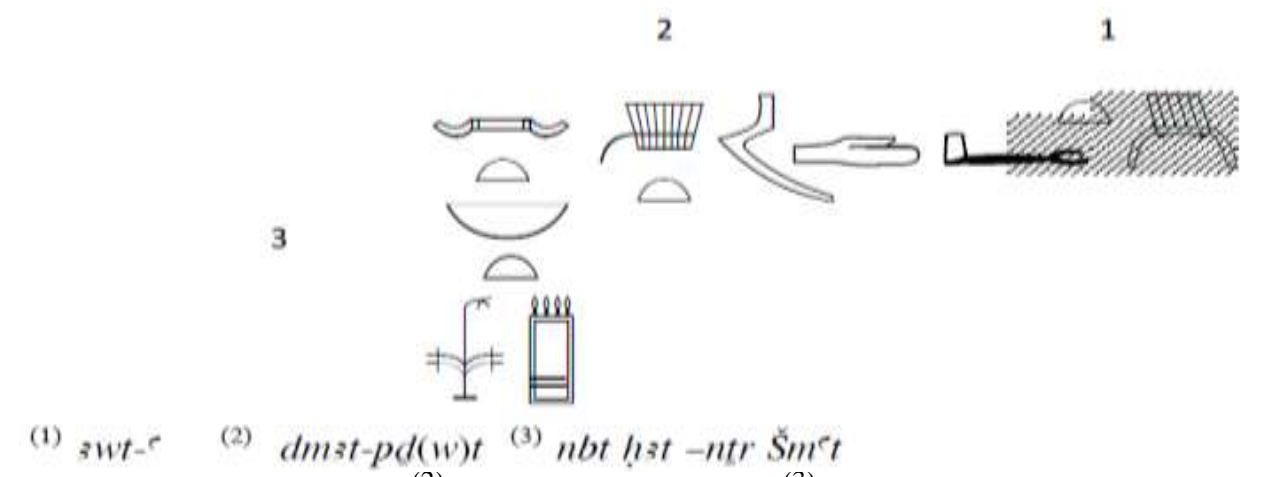

${ }^{(1)}$ With outstretched wings ${ }^{(2)}$ Stretcher of bows ${ }^{(3)}$ Mistress of the Upper Egyptian Divine Palace. Figure 4: Nekhbet protecting Sahure as a Griffin Trampling Enemies.

After: Borchadt (1913), Das grabdenkmal des königs Sa'hu-Re II, pl. 8.

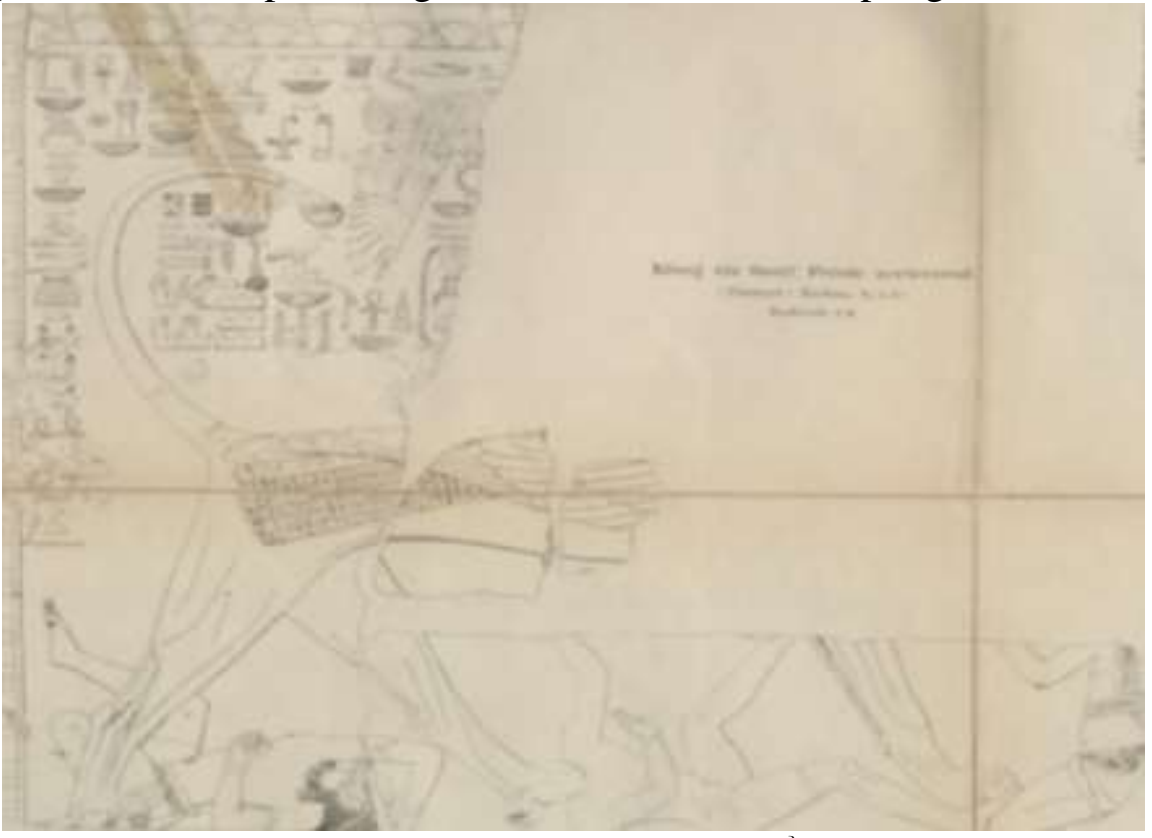

The fifth document was a limestone block come from the columned hall, funerary temple of Neuserre at Abusir ${ }^{*}$. Now preserved in Berlin Museum No. 16102 u. 17923-5. It showed goddess Nekhbet in the full avian form as a vulture outstretching her wings and hovering while holding the $\check{S} n$-sign in her claws.

Figure 5: The Vulture Goddess Nekhbet

"PM III', p. 338. 


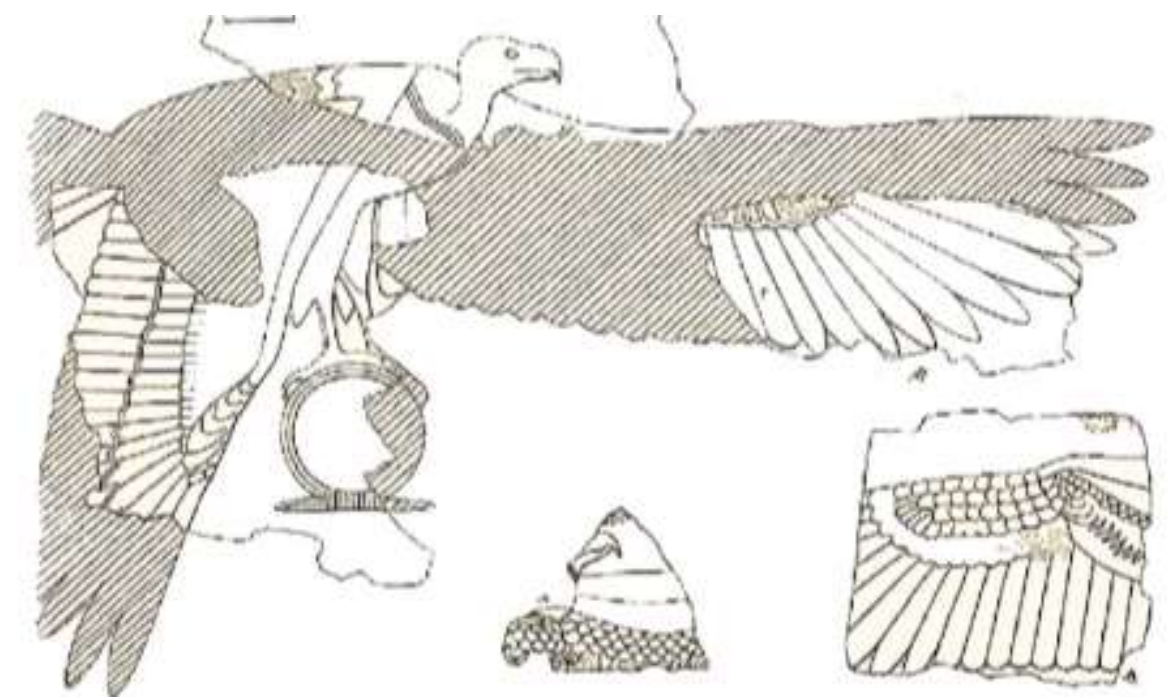

After: Borchadt (1907), Das grabdenkmal des königs Ne-User-Rer, pl. 67.

The sixth document was a scene from a granite door found on the northern wall from the antechamber of the funerary temple of Pepi II (2278-2184 B.C) at Saqqara*. It showed Pepi II receiving life from goddess Nekhbet in the presence of god Anubis who was depicted behind him. The illustration of the vulture goddess Nekhbet was shown above the king who protected him by outstretching her wings while grasping the $\breve{S} n$-sign.

Goddess Nekhbet was represented standing facing left. She was wearing above her head her vulture cap, around her neck the wsh-collar. She was wearing a tall-fitting dress with wide straps forming a low V-neck which left her right breast visible. She was holding in her left hand ' $n h$ - sing while her right was stretching towards the king's nostrils to give him life through the ' $n h$ - sign. Above her head was a short column of inscription traced from left to right $(\leftarrow \downarrow)$ which contained her titles as the following

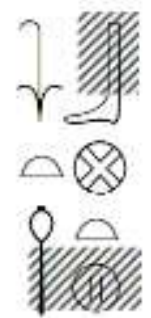

Nhbt $H \underline{d}$ l $N$ ln

Nekhbet, (She who is) The White of Nekhen.

Figure 6: Nekhbet is giving life to Pepi II in the presence of Anubis.

${ }^{*} \mathrm{PM} \mathrm{III}{ }^{2}$, p. 428. 


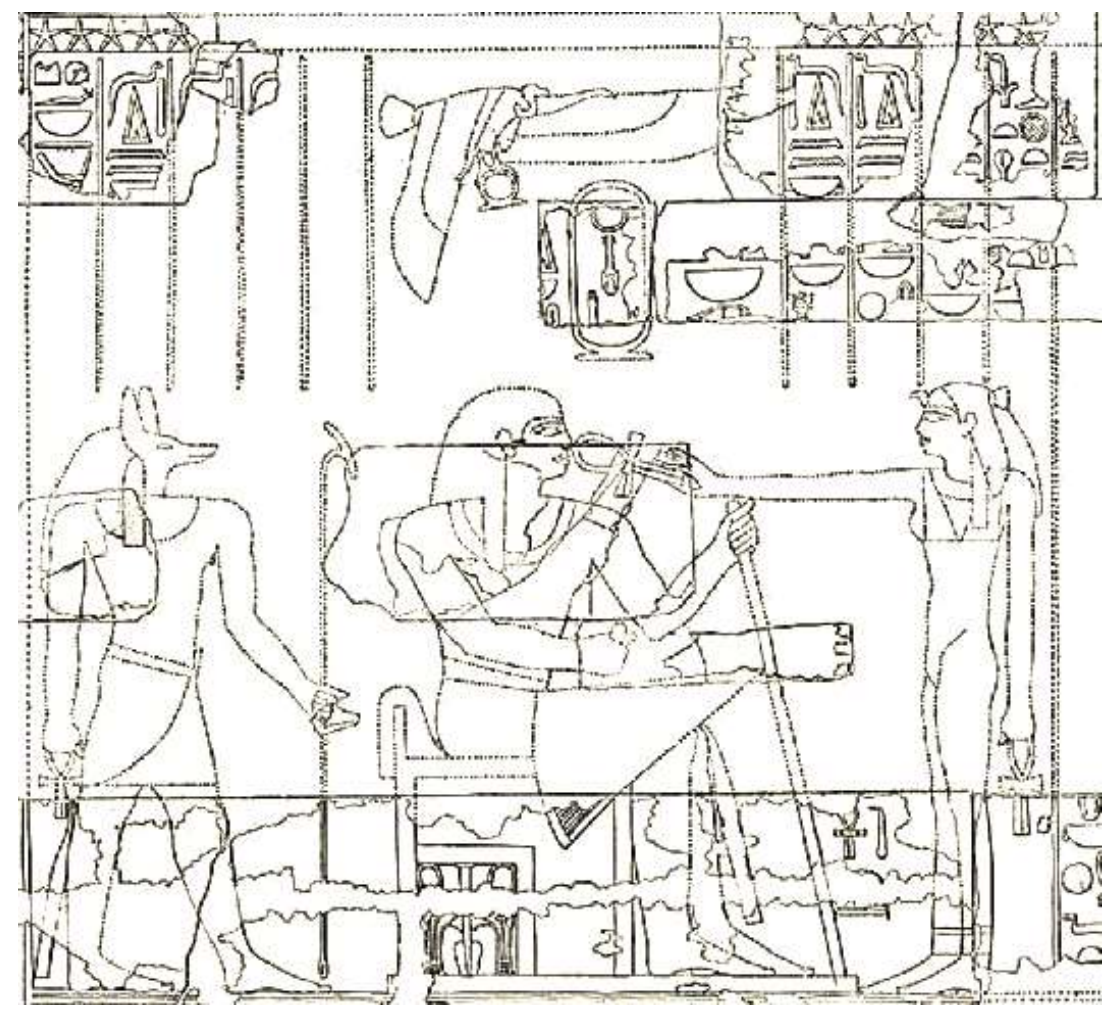

After: Jéquier (1938), Le monument funéraire de Pepi II II, pl. 54.

The last document was the limestone scene came from the vestibule of the funerary temple of Pepi II at South Saqqara ${ }^{*}$.It showed king Pepi II ready to hunt a hippopotamus with a harpoon. The vulture-goddess Nekhbet was shown hovering over the king's head with her wings outstretched and grasping the $\breve{S} n$-sign in her claws. Above and after her were two rows of inscriptions inscribed from right to left $(\downarrow \leftarrow)$ as the following

2
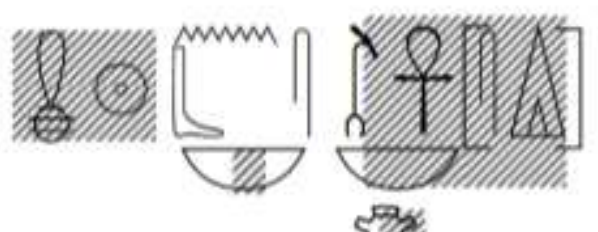

2) $\{$ di.s\} enh was $n b\{3 w i\} i b$ snb nb mi $R$

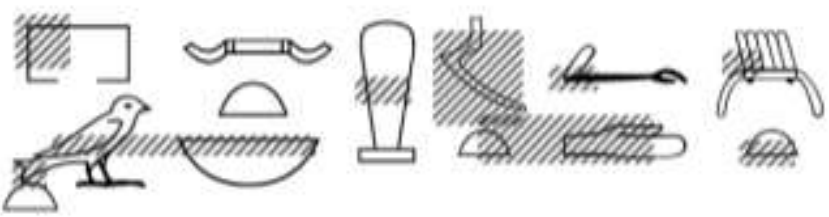

(1) With outstretched wings, Stretcher of bows, Mistress of the Great House ${ }^{(2)}$ \{She gives $\}$ all life, domination, joy, and all health like Re.

${ }^{*} \mathrm{PM} \mathrm{IIII}$, p. 426. 
Figure 7: Pepi II is Hunting a Hippopotamus under the Protection of Nekhbet

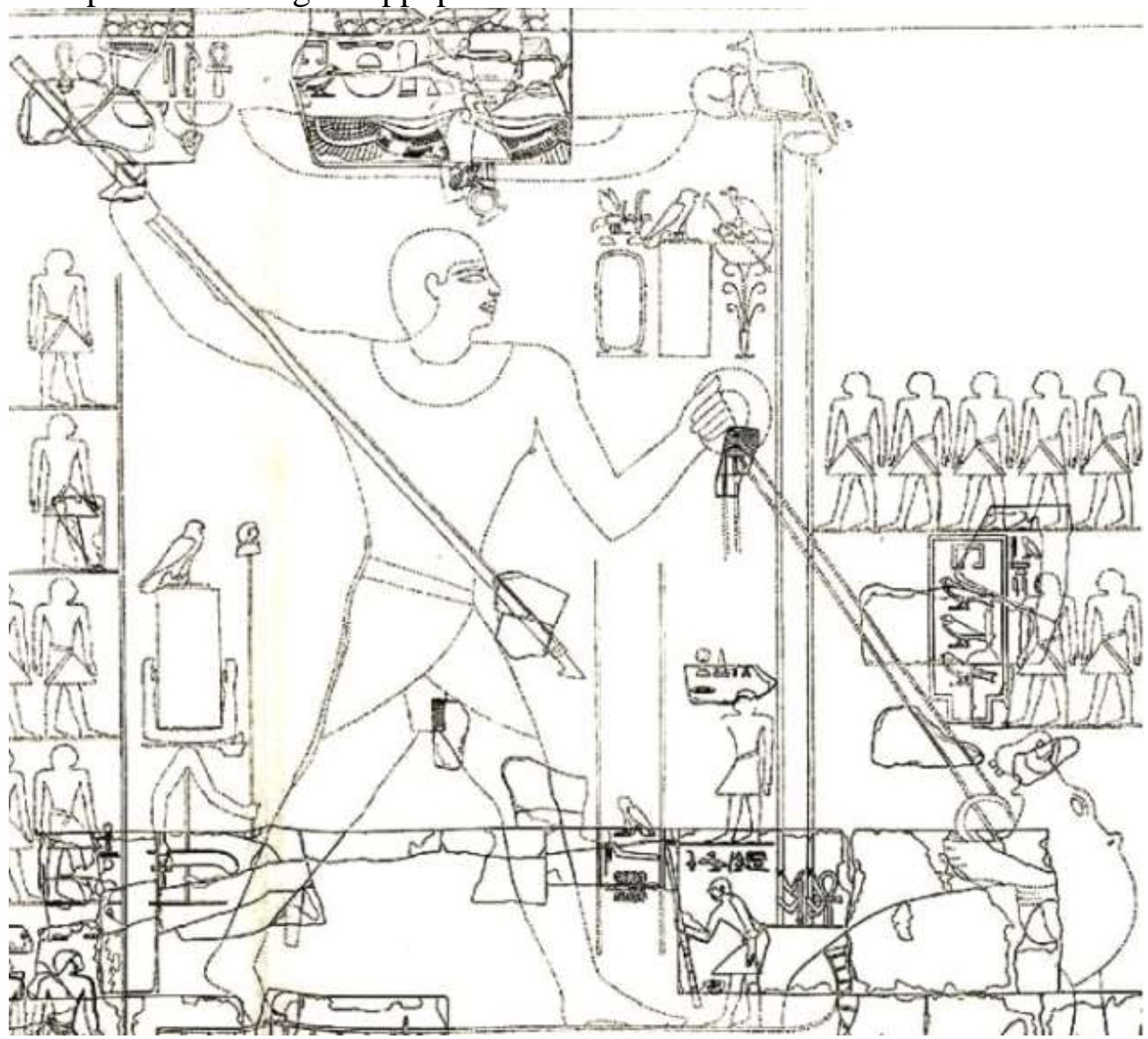

After: Jéquier (1940), Le monument funéraire de Pepi II III, pl. 32.

\section{Discussion and Results}

After this enumeration of the different scenes in relation with the goddess Nekhebet found on royal monuments during the fifth and sixth dynasties, certain points were determined as follows. The first conclusion one can confidently reach was that the paleography of goddess Nekhebet's name written on royal monuments during the fifth and sixth dynasties, the Ancient Egyptian scribe wrote the name in a detailed way; with two graphical forms: the first three phonetic signs $(n, h$ and $b)$ and the ideogram $-*$ Nhbt. The other form $c-\cdots$ of ideogram Nhbt 'f- , two phonetic complements ( $b$ and $t$ ) and the ideogram Nhn (iI) : the city of Hierakonpolis.

Regarding the nominations referring to the goddess Nekhebet, the geographical epithets of Nekhebet that connected the goddess with Lower Egypt cannot be noted thus far. However several epithets were connected to her main cult center in the third Nome of Upper Egypt: «H $\underline{H} t$ Nhn: The White of El- Kab», «Nhbt: the city of El-Kab» and «NbtPr-Wr: Mistress of the Great House ».

Moreover, Nekhebet bord several epithets which showed her relationship with Upper Egypt and its principal sanctuary: «Nbt 13t Ntr $5 m^{\top} w$ : Mistress of the Southern Sanctuary» and «Nbt itrt- 
$5 m^{\complement} w$ : Mistress of the chapel of Upper Egypt». One of her epithets refered to her specific place of cult at El-Kab: «Nbt $F^{e} g t$ : Mistress of $F^{e} g t »$. Nekhebet attained epithets that refered to her mighty character: «3wt-?: with outstretched wings» and «Dm3t-p $\underline{d}(w) t$ : Stretcher of Bows ».

Another conclusion was that goddess Nekhebet provided protection to the king. This aspect of the goddes as a protector deity was prominent in two scenes found on royal monuments during the fifth and sixth dynasties. One while while king Sahure was represented as a griffin trampling over enemies. The other when king Pepi II was hunting a hippopotamus.

Concerning the iconography of goddess Nekhbet, in art, she was depicted in two different forms: the full avian form as a vulture and anthropomorphic form. during the Old kingdom. Under the avian form, Nekhbet was usually depicted hovering with her wings spread above the royal image, holding a $\breve{S} n$ symbol (representing eternal encircling protection) in her claws.

In the full human form, Nekhbet was represented wearing a tripartite wig topped by her vulture cap; she wore a chocker around her neck and wsh-collar. She was dressed in a tall-tight dress with two wide straps along with bracelets and anklets. Her skin was colored pale cream.

\section{Conclusion}

In conclusion, the main epithets applied to Nekhbet were greatly reflected the different aspects and roles that the deity was able to play in the Egyptian pantheon. Geographical epithets of Nekhebet were the most common and important ones, especially those connected with the III ${ }^{\text {th }}$ Nome of Upper Egypt and its capital, Nekhen. This highlights the link between Nekhebet and her main cult center.

The Egyptians had always preferred to represent Nekhebet in a two different forms. The anthropomorphic form and the full avian form as a hovering vulture.

\section{References}

\section{Arabic References}

حسنين عزة .(1997). الإلهتان نخبت وواجيت منذ أقدم العصور وحتي نهاية الدولة الحديثة، رسالة دكتور اة، كلية الآثار،

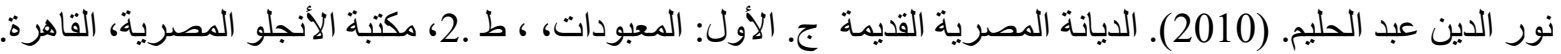

\section{Foreign References}

Bailleul-LeSuer Rozenn (2012), Between Heaven and Earth: Birds in Ancient Egypt. The Oriental Institute Museum Publications 35, Chicago: Oriental Institute.

Borchadt Ludwig (1907), Das grabdenkmal des königs Ne-User-Rea, Leipzig.

Budge E. A. Wallis (1904), The Gods of the Egyptians or Studies in Egyptian Mythology II, Methuen\& Co., London.

Budge E. A. Wallis (1904), The Gods of the Egyptians or Studies in Egyptian Mythology I, Methuen\& Co., London.

Capart Jean (1946), Quelques observations sur la déesse d' El- Kab, Foundations Égyptologique reine Èlisabeth, Bruxelles, pp. 1-15.

Černy Jaroslav (1951), Ancient Egyptian Religion, Hutchinson's University library, London. Corteggiani Jean-Pierre (2007), L'Égypte ancienne et ses dieux: dictionnaire illustré, Paris.

Erman Adolf and Grapow Hermann (1928), Wörterbuch der aegyptischen sprache II, Leipzig, p. 309.

Gardiner Alan (1975), Egyptian Grammar Being an Introduction to the Study of Hieroglyphs, $3^{\text {rd }}$ ed., Griffith Institute, Oxford. 
Gauthier Henri (1925), Dictionnaire des noms géographiques contenus dans les textshiéroglyhiques II, Le Caire.

Gauthier Henri (1926), Dictionnaire des noms géographiques contenus dans les textshiéroglyhiques III, Le Caire.

Gauthier Henri (1927), Dictionnaire des noms géographiques contenus dans les textshiéroglyhiques IV, Le Caire.

Hart George (2005), The Routledge Dictionary of Egyptian Gods and Goddesses, $2^{\text {th }}$ ed. London: Routledge.

Jéquier Gustave (1938), Le monument funéraire de Pepi II- tome II: Le temple, le Caire.

Jéquier Gustave (1940), Le monument funéraire de Pepi II- tome III: Les approches du temple, le Caire.

L.C.F. (2013), A Comprehensive List of Gods and Goddesses of Ancient Egypt. Book available on https://www.scribd.com/doc/154978105/Gods-and-Goddesses-of-Ancient-Egypt

Leitz Christian (2002), Lexikon der ägyptischenGötter und Götterbezeichnungen IV, OLA 113, Leuven, Paris and Dudley.

Lesko Barbara S. (1999), The Great Goddesses of Egypt, University of Oklahoma Press.

Montet Poerre (1961). Géographie de l'Égypte Ancienne II: 7A Sma, To-chemâ, La Haute Égypte, Librairie C. Klincksieck: Paris.

Pinch Geraldine (2002), Handbook of Egyptian Mythology, (Handbooks of World Mythology), Library of Congress Cataloging-in- Publication Data, ABC-CLIO Inc.

Porter Bertha and Moss Rosalind L. B. (1974), Topographical Bibliography of Ancient Egyptian Hieroglyphic Texts, Reliefs, and Paintings III: Memphis - Part I: Abu Rawash to Abusir, $2^{\text {nd }}$ ed., Oxford, Clarendon press.

Porter Bertha and Moss Rosalind L. B. (1981), Topographical Bibliography of Ancient Egyptian Hieroglyphic Texts, Reliefs, and Paintings III: Memphis - Part II: Șaqqâra to Dahshûr, Griffith Institute, Ashmolean Museum, Oxford.

Preys René (2010), "Nekhbet, L'øil droit du dieu solaire", in: Revue d'Égyptologie , tome 61, editions peeters, Paris.

Quibell James Edward (1912), The Monastery of ApaJeremias, IFAO, le Caire.

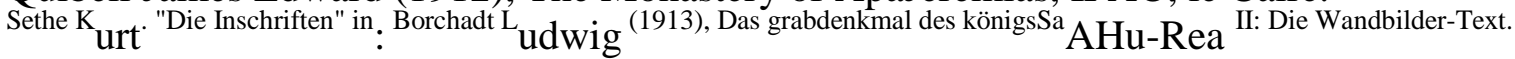

Voorschoten Matthieu Heerma Von Voss. 'Nechbet' in: Otta Eberhard and Helck Wolfgang. (1982), Lexikon der Ägyptologie, IV: Megiddo- Pyramiden, Wiesbanden, pp. 366-367.

Wahlberg Nina May (2002), Goddess Cults in Egypt Between 1070 BC and 332 BC, Ph.D Thesis, School of Historical Studies, University of Birminghan.

Werbrouck Marcelle (1952),."La déesse Nekhbet et la reine d'Égypte", in: HroznẎ BedŘich (eds.), Archiv Orientální XX, Czechoslovakia, pp.197-203.

Wilkinson Richard H. (2003), The Complete Gods and Goddesses of Ancient Egypt, New York: Thames \& Hudson. 